\title{
Competition between wild and captive-bred Penaeus plebejus and implications for stock enhancement
}

\author{
Faith Ochwada-Doyle ${ }^{1,2, *}$, Charles A. Gray ${ }^{1,2}$, Neil R. Loneragan ${ }^{3}$, Iain M. Suthers ${ }^{1,4}$, \\ Matthew D. Taylor ${ }^{1,2,4}$ \\ ${ }^{1}$ Evolution \& Ecology Research Centre, School of Biological, Earth and Environmental Science, \\ University of New South Wales, New South Wales 2052, Australia \\ ${ }^{2}$ Cronulla Fisheries Research Centre, NSW Industry and Investment, PO Box 21, Cronulla, New South Wales 2230, Australia \\ ${ }^{3}$ Centre for Fish, Fisheries \& Aquatic Ecosystem Research, School of Biological Sciences and Biotechnology, \\ Murdoch University, South St, Murdoch, Western Australia 6150, Australia \\ ${ }^{4}$ Sydney Institute of Marine Science, Building 22, Chowder Bay Road, Mosman, New South Wales 2088, Australia
}

\begin{abstract}
The mechanisms that drive density dependence are rarely studied in the applied context of population management. We examined the potential for competition for food and shelter and the resulting demographic density dependence to influence how well populations of the eastern king prawn Penaeus plebejus Hess can recover following marine stock enhancement programmes in which captive-bred juveniles are released into the wild. Specifically, manipulative laboratory experiments were used to quantify the differential effects of competition for food and competition for shelter on survival of wild and captive-bred P. plebejus as densities were increased and as each category of $P$. plebejus (wild or captive-bred) was supplemented with the alternate category. Increasing population densities when food and shelter were limited lowered survival for both categories. When food was limited, survival of both categories was unaffected by addition of the alternative category. Adding wild P. plebejus to their captive-bred counterparts when shelter was limited under laboratory conditions resulted in significantly higher mortality in captive-bred individuals. In contrast, adding captive-bred P. plebejus to wild individuals under these conditions did not affect wild P. plebejus. We conclude that if the current results can be extended to wild conditions, competition for shelter may lead to the loss of captive-bred P. plebejus, thereby reducing the intended outcomes of stock enhancement. This highlights the importance of investigating interactions between wild and captive-bred animals prior to stock enhancement to predict long-term outcomes and identify situations where stock enhancement could be an effective response to the loss of populations or recruitment limitation.
\end{abstract}

KEY WORDS: Re-stocking - Sea ranching - Penaeid - Shrimp - Complexity - Eastern Australia · Lotka-Volterra model $\cdot$ Penaeus (Melicertus) plebejus

Resale or republication not permitted without written consent of the publisher

\section{INTRODUCTION}

In the face of global habitat degradation and overexploitation in marine ecosystems, the effective management and conservation of living marine resources relies on a firm understanding of the processes that regulate population dynamics (Hixon \& Jones 2005, Rockwood 2006). Demographic density dependence, whereby a population's growth rate is limited by its size, plays a critical role in constraining population fluctuations within their upper and lower limits (Pile et al. 1996, Webster 2004). Competition is a common 
cause of density dependence in various habitats and communities (Connell 1983, Schoener 1983, Tilman 1987) and arises when the density of organisms that share the resources within a given area approaches the local carrying capacity (Connell 1983, Walls 1998). Competition often acts to lower densities by reducing the rate of demographic processes such as survival, growth and/or fecundity (Solomon 1949, Keeley 2001, Boaventura et al. 2002). Management and conservation programmes aimed at restoring and regulating populations should therefore consider their influence on competition and its densitydependent effects (Holbrook \& Schmitt 2002).

Stock enhancement and sea ranching programmes involve the release of large numbers of captivereared individuals into the wild to supplement exploited populations or increase fishery yields beyond levels supported by natural recruitment (Bell et al. 2006, 2008). Such management programmes can result in demographic density-dependent effects through competition for resources (Kleiman 1989, Molony et al. 2003, Støttrup \& Sparrevohn 2007). Stock enhancement has been attempted globally for a wide range of species, including marine and freshwater fish (Berejikian et al. 1997, Lenanton et al. 1999), lobsters (Agnalt et al. 1999), eels (Wickström et al. 1996) and abalone (Cook \& Sweijd 1999), and generally results in an abrupt increase in population densities and the sudden coexistence of wild and captive-bred conspecifics. Since these 2 categories of animals often show little to no niche differentiation for resources such as food and shelter (e.g. OchwadaDoyle et al. 2010), stock enhancements can result in competition between them at release sites with limited resources. If this competition is asymmetrical (i.e. it affects wild and captive-bred animals in different ways), it may lead to wild stocks restricting the survival, growth or fecundity of captive-bred individuals or captive-bred animals out-competing their wild counterparts (Fleming \& Gross 1993, Berejikian et al. 2001, Woodworth et al. 2002). While the first scenario may impede the intended outcome of a stock enhancement programme, the latter could lead to further declines in the density of the wild population or the accumulation of deleterious alleles from captive-bred animals (Blankenship \& Leber 1995, Ryer 2004, Araki et al. 2007).

Differential competitive abilities among wild and captive-bred animals can arise due to several factors. For instance, animals bred in captivity may be less effective competitors compared to wild animals due to changes in their behavioural, morphological or physiological phenotypes induced by rearing in a captive environment (Weber \& Fausch 2003). Such alterations can hinder the development of characteristics that were not required in captivity, but are essential for survival in the wild (Einum \& Fleming 2001). Alternatively, the conditions of a hatchery environment can endow captive-bred animals with a competitive advantage over their wild conspecifics. For example, the absence of predatory stimuli and the high rearing densities within some captive environments may select for individuals that forage aggressively (Weber \& Fausch 2003). The resulting hyper-aggression of captive-bred individuals can lead to the exclusion of their less aggressive and more cautious wild conspecifics through interference competition (Mason \& Chapman 1965, Branch 1984).

Historically, the impact of increased competition between wild and captive-bred animals at release sites has only been realised after significant resources have been invested in large-scale releases. For example, 2 yr after releasing 1950 to 3885 captive-reared brook trout Salvelinus fontinalis into each of 6 lakes ( 0.13 to $0.25 \mathrm{~km}^{2}$ in size) in Quebec, Canada, asymmetric competition with native competitors was identified as the cause of low survival and reduced growth rates among captive-bred individuals (Lachance \& Magnan 1990). Recreational anglers, who were the intended beneficiaries of the stocking programme, consequently experienced low $(0.031$ to $0.50 \%)$ recovery of released $S$. fontinalis (Lachance \& Magnan 1990). Only in recent years have preliminary evaluations been encouraged to examine the possible ecological impacts of stock enhancements and determine the factors that may limit the survival of released individuals (Sarrazin \& Barbault 1996, Leber 1999, Taylor et al. 2005, Bose \& Sarrazin 2007). An integral part of this evaluation process is the use of experiments to examine the effect of stock enhancement on ecological interactions such as competition.

Here we used laboratory experiments to examine competition between captive-bred and wild eastern king prawn Penaeus plebejus Hess. Note that this species' name was previously changed to Melicertus plebejus following the elevation of several subgenera of Penaeus to the level of genus by Pérez Farfante \& Kensley (1997). However, the revised nomenclature has been controversial for some taxa (e.g. Lavery et al. 2004, Flegel 2007, 2008, McLaughlin et al. 2008), and the original names have consequently been retained for Australian species, following Baldwin et al. (1998) and Lavery et al. (2004). P. plebejus was chosen as the test species for this study because it is a current candidate for stock enhancement along the 
east coast of Australia (e.g. Taylor 2010). Like other penaeids (Minello \& Zimmerman 1985, Skilleter et al. 2005), this species has mainly been shown to exhibit a strong association with macrophytic habitat during the nursery phase of its life cycle (Young 1975, 1978, Ochwada et al. 2009). This penaeid-macrophyte association has usually been attributed to the abundance of feeding resources and shelter from predators available within macrophytes (Kitting et al. 1984, Kenyon et al. 1995, Liu \& Loneragan 1997, OchwadaDoyle et al. 2010). We therefore used experiments to quantify the effect of competition for food and refuge within artificial macrophytes on the survival of juvenile captive-bred and wild P. plebejus as densities are increased and as the alternative category of juveniles (wild or captive-bred) is added to each category.

We predicted that the absence of predatory stimuli and the high rearing densities typical of penaeid hatcheries would favour aggressive behaviours in captive-bred Penaeus plebejus and that this would lead to the competitive dominance of this category. For each of food and shelter, we therefore hypothesised that (1) mortality due to competition would increase as densities were increased for both wild and captive-bred P. plebejus and (2) mortality due to competition between the 2 categories would be greater than mortality due to competition within wild P. plebejus, but lower than that within captive-bred P. plebejus. The results are discussed in the context of the Lotka-Volterra theory on competition to explore the implications for the long-term coexistence of captive-bred and wild P. plebejus following stock enhancement. We conclude that competition for shelter may lead to high mortality among captivebred P. plebejus and that this could potentially limit the intended outcomes of stock enhancement.

\section{MATERIALS AND METHODS}

\section{Study species}

Penaeus plebejus is endemic to the east coast of Australia (Courtney et al. 1995), and its distribution ranges from central Queensland to eastern Victoria and the waters of north-eastern Tasmania (Montgomery et al. 2007). Adult P. plebejus spawn from $\sim 9$ mo of age, and spawning takes place in warmer offshore waters within the northern ranges of the species' distribution (Racek 1959, Ruello 1975, Courtney et al. 2002). Spawning in this species has been reported to occur principally between January and
June (Racek 1959, Ruello 1975). Large females (between 4 and $6 \mathrm{~cm}$ in carapace length, CL) can produce up to 1 million planktonic eggs which hatch into nauplius larvae in offshore waters (Dall et al. 1990a). These larvae are then transported southward to shallow nursery habitats within estuaries via the Eastern Australian Current (Montgomery 1990, Rothlisberg et al. 1995). The larvae remain within these nursery habitats, where they develop into juveniles (Young 1978, Reid \& Montgomery 2005). During the nursery phase of the penaeid lifecycle, structured habitats generally support more individuals (Heck \& Thoman 1984, Hill \& Wassenberg 1993). For P. plebejus, juveniles are usually more abundant in macrophyte beds than adjacent bare habitats at small spatial scales (Young 1978), and their densities are often positively correlated with macrophytic cover (Skilleter et al. 2005). Macrophytes and their epiphytes have been shown to contribute to the juvenile penaeid diet (Kitting et al. 1984, Loneragan et al. 1997). Experimental work has also shown that predation by fish on postlarval and juvenile P. plebejus in estuaries is significantly lower in macrophyte habitats compared to bare areas (Ochwada et al. 2009, Ochwada-Doyle et al. 2010). Once maturing juveniles reach a mean $( \pm \mathrm{SE}) \mathrm{CL}$ of between $1.90 \pm 0.01 \mathrm{~cm}$ and $2.84 \pm$ $0.02 \mathrm{~cm}$ (total length, TL, 7.6 to $11.68 \mathrm{~cm}$ ), they begin to emigrate from estuarine waters and move northward along the coast towards the species' spawning grounds (Ruello 1975). P. plebejus is a fastgrowing species with a life cycle that can extend to 3 yr (Ruello 1975).

\section{Sampling and preparation of study species}

Wild juveniles $(W)$, which were produced without human intervention and had recruited into an open lake on the south-eastern coast of Australia (Merimbula Lake; $36^{\circ} 53^{\prime} 51^{\prime \prime} \mathrm{S}, 149^{\circ} 53^{\prime} 05^{\prime \prime} \mathrm{E}$ ), were collected at an average size $( \pm \mathrm{SE})$ of $4.46 \pm 0.03 \mathrm{~cm}$ in TL (CL $\sim 1.11 \mathrm{~cm}$ ). Wild Penaeus plebejus were captured using an epibenthic sled with an opening of $80 \times 45 \mathrm{~cm}$ and a $2 \mathrm{~m}$ long, $2 \mathrm{~mm}$ stretch-mesh net which was towed by hand over macrophytic habitat within Merrimbula Lake. Once captured, $W$ P. plebejus were transported in aerated $50 \mathrm{l}$ tanks to a flow-through, coarse filtered aquarium facility at Cronulla Fisheries Research Centre (34 04' 21" S, $151^{\circ} 08^{\prime} 56^{\prime \prime}$ E) $3 \mathrm{~d}$ prior to their use in the experiments. At the research centre, they were transferred into $2500 \mathrm{l}$ fiberglass holding tanks lacking any form of substrate or predatory stimulus. They 
were held in these tanks at densities of $46,44,54$ and 50 ind. $\operatorname{tank}^{-1}$.

Captive-bred $(C)$ juveniles were produced in a commercial hatchery (Rocky Point Aquarium, Gold Coast, Australia) using 97 wild brood-stock ( 1:96 male to female sex ratio with many of the females already inseminated when collected) collected from coastal waters off central eastern Australia (between $30^{\circ} 16^{\prime} 49^{\prime \prime} \mathrm{S}, 153^{\circ} 12^{\prime} 06^{\prime \prime} \mathrm{E}$ and $24^{\circ} 45^{\prime} 06^{\prime \prime} \mathrm{S}$, $\left.153^{\circ} 01^{\prime} 22^{\prime \prime} \mathrm{E}\right)$. After hatching, the $C$ individuals were reared in the hatchery for $18 \mathrm{~d}$. During this early rearing period, the $C$ Penaeus plebejus were held in $40000 \mathrm{l}$ parabolic fiberglass tanks at densities of approximately 200000 ind. $\operatorname{tank}^{-1}$ and fed commercial hatchery pellets $\left(1.5 \mathrm{ltank}^{-1} \mathrm{~d}^{-1}\right)$ consisting of marine and plant proteins, plant meals, yeast, algae, marine oils, vitamins and antioxidants. The tanks lacked any form of substrate or predatory stimulus. After $18 \mathrm{~d}$, the $C$ P. plebejus were transported in $10 \mathrm{l}$ of water in sealed plastic bags carried within sealed boxes to Cronulla Fisheries Research Centre where they were held within 25001 fiberglass holding tanks at densities of 41, 56, 51 and 43 ind. $\operatorname{tank}^{-1}$. They were reared for a further $48 \mathrm{~d}$ to an average TL (as measured from a haphazardly selected subsample of juveniles) of $4.03 \pm 0.05 \mathrm{~cm}(\mathrm{CL} \sim 1.00 \mathrm{~cm})$. The feeding regime from the early rearing period was maintained up until $3 \mathrm{~d}$ prior to the experiments, and the holding tanks at Cronulla Fisheries Research Centre also lacked substrates or predatory stimulus.

Three separate experiments were conducted in this study to examine (1) the effects of tagging on the survival of juveniles; (2) competition for feeding resources between $W$ and $C$ juveniles within artificial macrophytes; and (3) competition for refuge from predators between $W$ and $C$ juveniles within artificial macrophytes. These experiments are referred to hereafter as 'tagging study', 'competition for food' and 'competition for refugia', respectively. The $W$ and $C$ juveniles used in each competition experiment were taken from the holding tanks $12 \mathrm{~h}$ before the experiments began. The juveniles were then sedated by placing them in iced water and tagged using VI Alpha Numeric Tags (Northwest Marine Technology, $1.2 \mathrm{~mm} \times 2.7 \mathrm{~mm}$ ) inserted laterally into their last abdominal segment beneath the exoskeleton. These tags allowed individual juveniles to be identified. The wet weight of each juvenile was measured to the nearest $0.1 \mathrm{~g}$ immediately after tagging and before being allocated to a treatment in each competition experiment. There were no significant differences between $W$ and $C$ juveniles in terms of weight in the competition for food experiment $(t=1.55 ; \mathrm{p}=0.26$; $\mathrm{n}=3 ; \alpha=0.05)$ and in the competition for refugia experiment $(t=0.33 ; \mathrm{p}=0.77 ; \mathrm{n}=3 ; \alpha=0.05)$.

\section{Experimental tanks}

The tagging study was conducted in 2 separate 1001 fiberglass treatment tanks (radius: $25 \mathrm{~cm}$; height: $50 \mathrm{~cm}$ ), and each treatment tank was replicated twice. These tanks did not contain any form of substrate or predatory stimulus. Each competition experiment was conducted in 9 separate 1001 fiberglass treatment tanks, with 3 replicate tanks of each treatment. The floor of each tank was covered by artificial macrophytes composed of AquaMat ${ }^{\circ}$, a positively buoyant synthetic matting with a high microscopic surface area. The AquaMat ${ }^{\circledR}$ was divided into $25 \mathrm{~cm}$ high $\times 1.5 \mathrm{~cm}$ wide blades attached to a weighted basal length of the same synthetic matting. Three $20 \mathrm{~cm}$ basal lengths of AquaMat ${ }^{\odot}$, each with approximately 13 attached blades, were haphazardly placed on the floor of each tank to make up a density of blades that was equivalent to a high shoot density of approximately 200 shoots $\mathrm{m}^{-2}$ (see Webster et al. 1998) and a surface area of $0.75 \mathrm{~m}^{2}$ of macrophytic structure per $\mathrm{m}^{2}$ of substrate. AquaMat ${ }^{\circledR}$ effectively simulates the blades and leaves of macrophytes in the wild (Arnold et al. 2005). Prior to placing the AquaMat ${ }^{\odot}$ into the tanks used to examine competition for food, the AquaMat ${ }^{\odot}$ units were left within a natural bed of seagrass (mainly Posidonia australis Hooker f. and Zostera capricorni Aschers; Kirkman \& Reid 1979) near the aquaria facility for $21 \mathrm{~d}$. This facilitated colonisation of the units by natural microbiota and epiphytes upon which the Penaeus plebejus could feed. In the competition for refugia experiment, the AquaMat ${ }^{\odot}$ was not conditioned before use. The average ( $\pm 1 \mathrm{SE}$ ) dissolved oxygen (DO), temperature and salinity across all tanks during all experiments of the study was $12.1 \pm 0.07 \mathrm{mg} \mathrm{DO} \mathrm{l}^{-1}, 20 \pm$ $1.42^{\circ} \mathrm{C}$ and $36.6 \pm 0.05$, respectively.

\section{Experimental design}

\section{Tagging study}

Twelve juvenile Penaeus plebejus haphazardly selected from the $W$ and $C$ categories were used in the tagging study. From these 12 juveniles, 6 individuals were haphazardly sub-sampled (irrespective of category), weighed to the nearest $0.1 \mathrm{~g}$ and placed at 

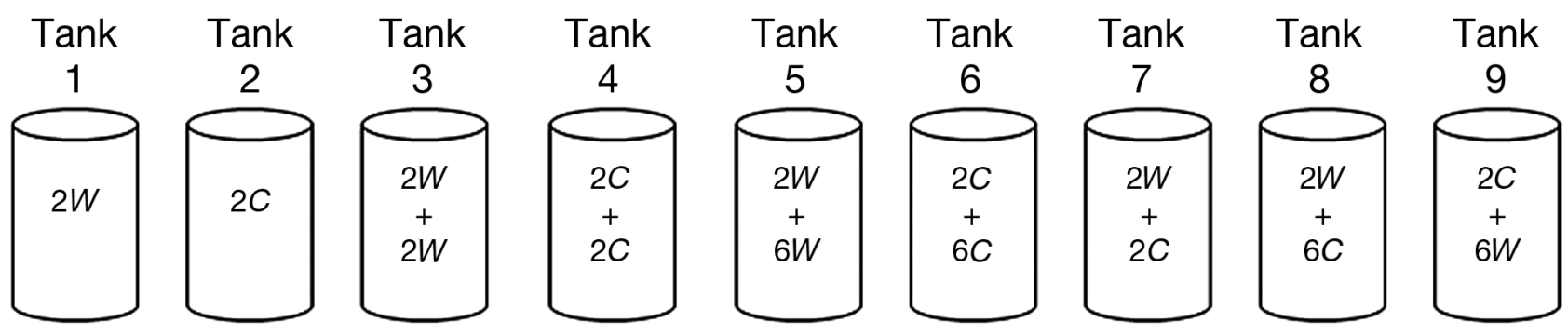

Fig. 1. Penaeus plebejus. Densities and combinations of wild $(W)$ and captive-bred $(C)$ juveniles in 9 treatment tanks used to examine competition among and between the 2 categories of juveniles. Each tank was replicated 3 times (n = 3)

equal densities into 2 independent replicate tanks, creating a nested design with 3 replicate juveniles tank $^{-1}$ in 2 replicated tanks which were in turn nested in the Untagged treatment. The remaining 6 juveniles were sedated, weighed and tagged with the VI Alpha Numeric Tags. They were then placed into each of the remaining 2 independent replicate tanks at equal densities, repeating the nested design of 3 replicate juveniles tank ${ }^{-1}$ in 2 replicated tanks nested in the Tagged treatment. This experiment only assessed the effect of tagging on the survival of P. plebejus and assumed that the effects of tagging would not be significantly different between wild and captive-bred juveniles. The densities used in each tank were equivalent to a density of approximately 16 juveniles $\mathrm{m}^{-2}$. After $28 \mathrm{~d}$, during which the juveniles were fed hatchery pellets every second day, the number of juveniles that were dead or alive within each tank was recorded.

\section{Competition for food}

Experiments examining competition between 2 or more groups of animals need to be able to separate the effects of increased density from the effects of competition between the groups of animals in ques- tion (Olabarria et al. 2002, Weber \& Fausch 2003). We used 9 separate tanks with different densities and combinations of $W$ and $C$ juveniles (Fig. 1, Table 1). This design facilitated simultaneous investigation of 4 aspects of competition: (1) the effect of competition on $W$ juveniles as densities are increased (irrespective of which category of juveniles is added to induce the density increase); (2) the effect of competition on $C$ juveniles as densities are increased (irrespective of which category of juveniles is added to induce the density increase); (3) the effect of competition between $W$ and $C$ juveniles on $W$ juveniles (i.e. the specific effect on $W$ juveniles caused by addition of $C$ juveniles to the former); and (4) the effect of competition between $W$ and $C$ juveniles on $C$ juveniles (i.e. the specific effect on $C$ juveniles caused by addition of $W$ juveniles to the former; Fig. 1, Table 1). Each of these aspects was measured and analysed independently for $W$ and $C$ juveniles. For each category of $W$ or $C$ juveniles, the design therefore examined the effects of 2 main factors: (1) the effect of increasing density (ID) and (2) the effect of having the alternative category of juveniles added (category added, CA).

To examine competition for food between $W$ and $C$ juveniles, tagged juveniles from each category $(24 \mathrm{~W}$ and $24 C$ ) were added to the 9 treatment tanks at the densities and combinations shown in Fig. 1. In previ-

Table 1. Penaeus plebejus. Treatment tanks used to assess how the proportional survival of wild $(W)$ and captive-bred $(C)$ juveniles was affected by increasing densities or addition of the alternative category of juveniles (refer to Fig. 1). For each treatment, there were $\mathrm{n}=3$ replicate tanks

Test

Treatment tanks used

1. Effect of competition on $W$ juveniles as densities are increased

$1,3,5,7,8$

2. Effect of competition on $C$ juveniles as densities are increased

$2,4,6,7,9$

3. Effect of between-category competition on $W$ juveniles when $C$ juveniles are added to them

$3,5,7,8$

at increasing densities

4. Effect of between-category competition on $C$ juveniles when $W$ juveniles are added to them at increasing densities

$4,6,7,9$ 
ous stock enhancement experiments with a closely related penaeid species (Penaeus semisulcatus), density-dependent effects were not observed in seagrass beds with a high shoot density until the density exceeded 10 prawns $\mathrm{m}^{-2}$ (Loneragan et al. 2001). This density, which is equivalent to a density of about 2 juveniles $\operatorname{tank}^{-1}$ for the tanks used in the present study, was therefore chosen as the control density for each category, and it was predicted that at higher densities the macrophyte-based resources (food and refugia) used by penaeids would become limiting. The higher experimental densities used here represented 2 and 4 times the control density (i.e. 4 and 8 juveniles tank ${ }^{-1}$ or $\sim 20$ and 40 juveniles $\mathrm{m}^{-2}$, Fig. 1).

The experiment examining competition for food commenced immediately after the appropriate densities of $W$ and $C$ juveniles had been added to each tank and ran for $4 \mathrm{wk}$. During this time, tanks were monitored daily and dead juveniles and moults were removed. At the end of the experiment, each tank was drained of water and the number of surviving Penaeus plebejus from each category was determined. The relevant categories and treatments were then compared in terms of the proportion of $W$ or $C$ individuals surviving at the end of the experiment (Table 1).

\section{Competition for refugia}

A similar experiment was used to examine competition for refugia between $W$ and $C$ Penaeus plebejus in the presence of a predator. The AquaMat ${ }^{\ominus}$ used in the competition for refugia experiment did not have a film of biota on its surface. Each tank contained a predatory fish (adult Centropogon australis, average $\mathrm{TL}=10.02 \pm 0.43 \mathrm{~cm})$. C. australis were sampled from macrophytic habitats in Merimbula Lake $5 \mathrm{~d}$ before use in the experiment using a $10 \mathrm{~m}$ beach seine constructed with $5 \mathrm{~mm}$ stretch-mesh netting. The predators were transported to the aquarium facilities within an aerated tank (50 l) and then housed in a $100 \mathrm{l}$ tank prior to the experiments. During this time, C. australis were fed with commercially purchased prawn flesh every second day. C. australis were added to each of the treatment tanks $2 \mathrm{~h}$ after tagged juvenile $P$. plebejus (24 $W$ and $24 C$ ) had been added to the tanks at the densities and combinations shown in Fig. 1, and the experiment ran for 1 wk. During the week-long experiment, hatchery pellets were added to each tank on every third day to provide feed for the $P$. plebejus but no supplemental feed was added for the $C$. australis. At the end of the experiment, the tanks were drained and the C. australis and P. plebejus were located and removed. The numbers of $W$ and $C$ juveniles surviving in each tank were counted, and differences in proportional survival of $W$ and $C$ juveniles between relevant categories and treatments were compared (Table 1).

\section{Statistical analysis}

Since the tagging study only had 2 replicate tanks in each treatment and very few animals per tank, we sought to combine data among the replicate tanks by using a nested experimental design and analysis. In order to justify combining data among replicate tanks of a treatment, a nested generalised linear model (GLM), assuming a quasi-binomial distribution (which allows for non-independence; Fox 2008), was first used to examine variation between replicate tanks in terms of the probability of a juvenile surviving. Survival was treated as a binary variable in the model $(0=$ dead, $1=$ alive $)$. If variation between replicate tanks was not significant at $\alpha=0.05$, it was examined again at $\alpha=0.25$ so that the probability of making a Type II error (i.e. retaining the null hypothesis of no difference between replicate tanks when it is in fact false) was minimised (Underwood 1997). If the latter test also showed that there was no significant variation among replicate tanks, combining animals in replicate tanks of each treatment was justified and the main factor in the GLM (Treatment: Tagged versus Untagged) was then examined to determine whether the tagging treatment was associated with the probability of a juvenile being alive at the end of the study at $\alpha=0.05$. For the GLM, partial $z$-tests were used to test the null hypothesis that $\beta_{i}=$ 0 for each factor in the model, where $\beta_{i}$ was the partial regression coefficient for a factor. It must be noted that the tagging study was a pilot-scale experiment, and the results should therefore be interpreted with some caution.

For each competition experiment, an asymmetrical analysis of variance (ANOVA, $\alpha=0.05$ ) similar to that described by Underwood (1997) was used to examine the effect of competition on each of $W$ and $C$ juveniles separately (Table 2). The ANOVAs for each category were conducted separately to avoid nonindependence of data, resulting in a total of 5 treatment tanks being compared in each analysis. The analyses examining the effects of competition on $W$ juveniles considered only the $W$ juveniles in tanks 1 , $3,5,7$ and 8 , while those examining the effects of competition on $C$ juveniles considered only the $C$ 
Table 2. Penaeus plebejus. Asymmetrical design for the separate analyses of variance (ANOVAs) used to examine the effects of competition on either wild $(W)$ or captive-reared $(C)$ juveniles. For effects on each category, survival data from 5 treatment tanks (any one of which are represented by $i$ ) were first analysed by a single-factor ANOVA. The degrees of freedom (df) and sum of squares derived from this ANOVA were used to calculate the mean-square estimates (MS) for the sources of variation in the asymmetrical ANOVA annotated with superscript a. Data from 4 non-control tanks were then analysed in a 2-factor ANOVA (with increased density, ID, and addition of the alternative category, CA, as the 2 fixed factors) to calculate the MS for the sources of variation annotated with superscript $b$. Any given treatment of the factor ID is represented by $j$ and any given treatment of the factor CA is represented by $k . \mathrm{n}=3$ replicate tanks for all treatments, and each asymmetrical ANOVA examined variation in proportional survival (1) among treatments and (2) within treatments (the latter was measured by variation among the 3 independent replicate tanks of each treatment). Since all factors in the analyses were fixed, all sources of variation were tested against the residual mean-square calculated in the single factor ANOVA. $\sigma_{e}^{2}$ is the variance with which the samples are distributed around their mean

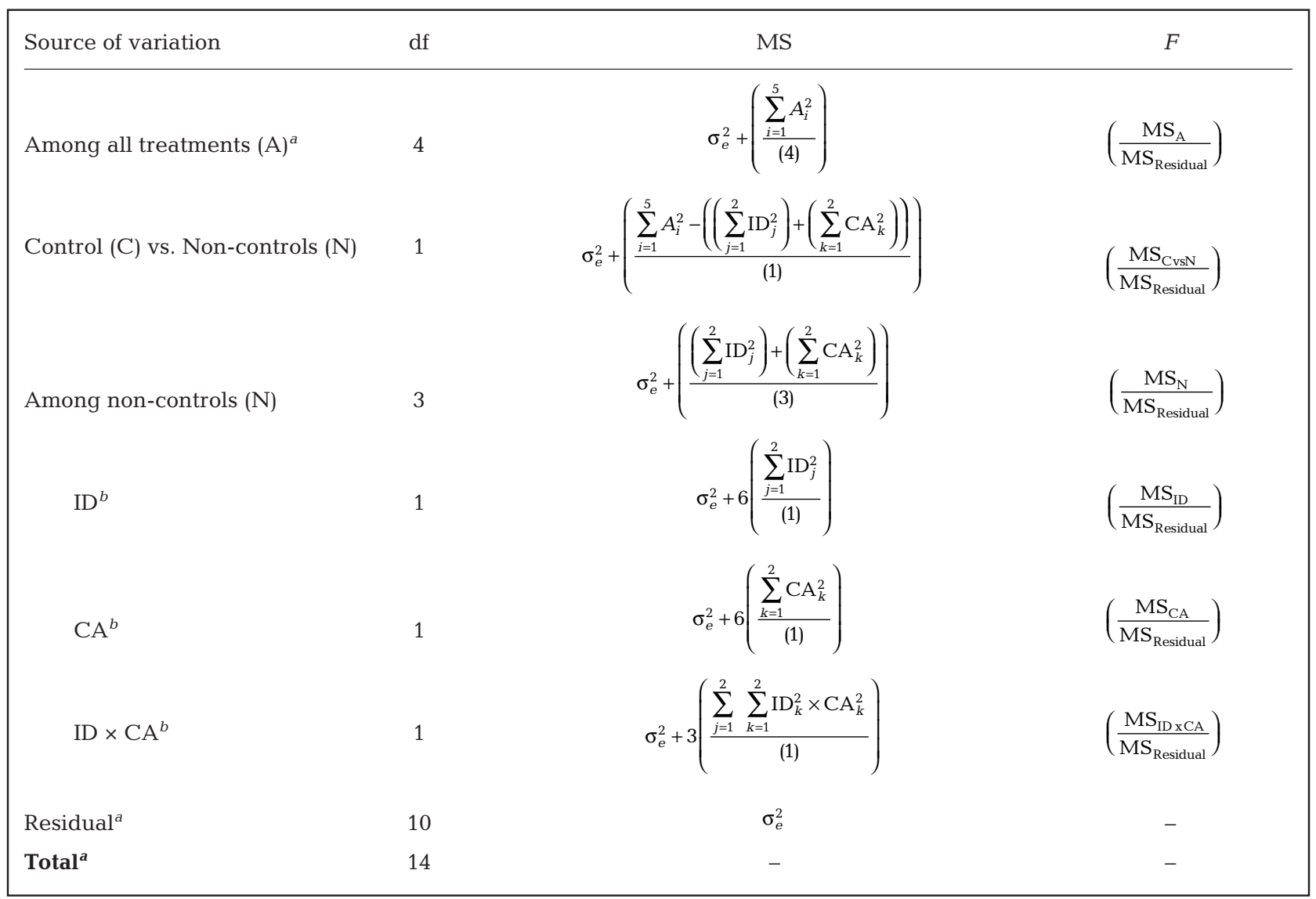

juveniles in tanks 2, 4, 6, 7 and 9 (Fig. 1, Table 1). The proportional survival of $W$ in a particular tank, for example, was calculated as the total number of $W$ individuals surviving in that tank at the end of the experiment divided by the total number of $W$ individuals initially put into that tank. The asymmetry in the design was created by the fact that there was only 1 set of control density treatments for each category, which precluded the symmetry needed to match the non-control levels of the factor ID and the levels of the factor CA in an orthogonal design.

If the ID $\times$ CA was not significant, the F-ratios of the main effects from the 2-factor ANOVA could then be used to determine the effects of ID and CA on either $W$ or $C$ individuals. If the ID $\times$ CA interaction was significant, Student-Newman-Keuls (SNK) tests ( $\alpha=0.05$ ) and examination of means were employed, respectively, to determine the effects of ID and CA separately.

\section{RESULTS}

\section{Tagging study}

For the tagging experiment, the nested GLM showed that at both $\alpha=0.05$ and $\alpha=0.25$, the probability of a juvenile surviving was not significantly dif- 

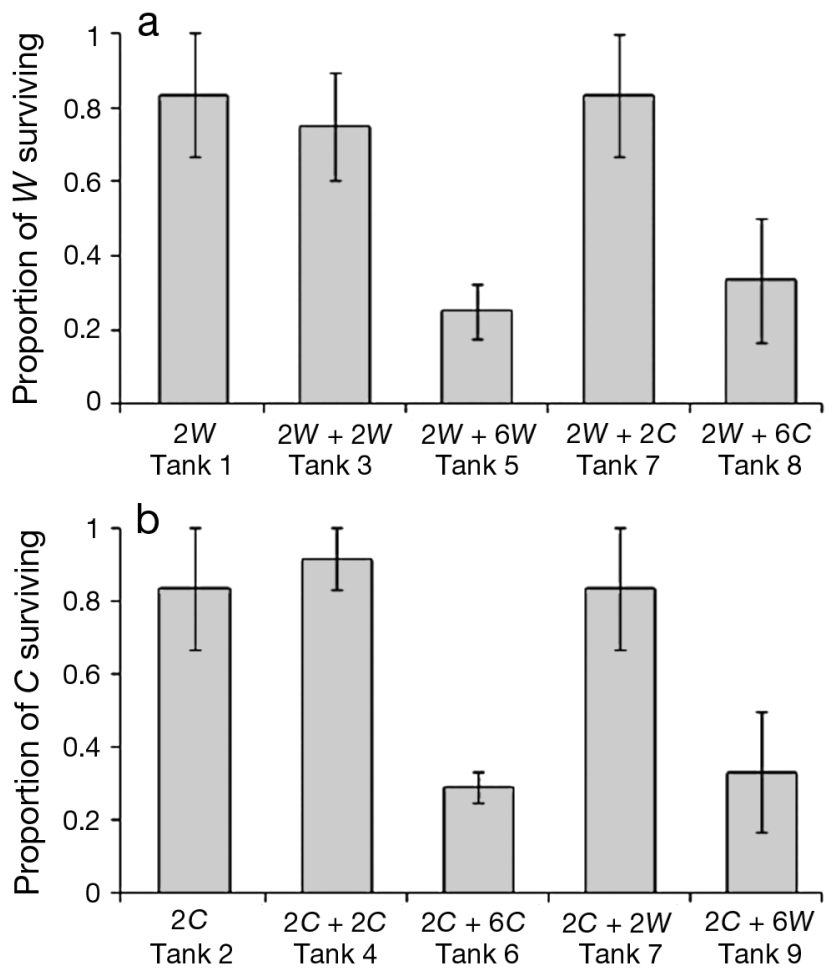

Fig. 2. Penaeus plebejus. Mean $( \pm \mathrm{SE})$ proportional survival of (a) wild $(W)$ and (b) captive-bred $(C)$ juveniles in an experiment examining competition for food within and between the 2 categories. Treatment tanks contained different combinations and densities of each category of juveniles (see Fig. 1)

ferent between replicate tanks in the Tagged treatment $(\mathrm{p}(>|z|)=0.47)$ or the Untagged treatment $(p(>|z|)=1.00)$. Combining individual prawns from the replicate tanks was therefore justified, and the GLM showed that the probability of a juvenile surviving was not significantly different between the Tagged and Untagged treatments $(p(>|z|)=0.47)$.

\section{Competition for food}

Across all tanks used, the first mortalities during the experiment occurred on Day 16 within replicates of tank $6(2 C+6 C)$ and tank $7(2 W+2 C)$. From Day 19 and thereafter, mortalities began occurring in all of the other treatment tanks. The average proportional survival of $W$ juveniles declined gradually when the control density of $W$ individuals was doubled, and this decline was marked when this density was quadrupled (Fig. 2a). The ANOVA showed that the overall effect of ID on the survival of $W$ juveniles was significant (Table 3). At a density of 8 juveniles tank $^{-1}$, survival of $W$ juveniles when $C$ juveniles were added to them $(2 W+6 C)$ was similar to that observed when $W$ juveniles existed alone at the same density ( $2 W+6 W_{i}$ Fig. 2a). Survival of $W$ juveniles at a density of 4 juveniles tank ${ }^{-1}$ was also similar between tanks in which $C$ juveniles were added to $W$ juveniles $(2 W+2 C)$ and those in which $W$ juveniles existed alone $(2 W+2 W$; Fig. $2 \mathrm{a})$. The ANOVA confirmed that the effect of adding $C$ juveniles on the survival of $W$ juveniles, as quantified by the CA factor, was not significant (Table 3).

When the density of $C$ individuals was increased, there was a slight initial increase in the proportional survival of $C$ followed by a marked decline in proportional survival at the highest densities (Fig. 2b), and the effect of ID on the survival of $C$ juveniles in the ANOVA was significant (Table 4). Survival of $C$ juveniles when $W$ juveniles were added to them $(2 C+2 W$ and $2 C+6 W$ ) was not significantly different from that observed when $C$ juveniles existed alone $(2 C+2 C$ and $2 C+6 C$; Fig. 2b, Table 4).

\section{Competition for refuge}

In the presence of a predator, the proportional survival of $W$ individuals was significantly lower in tanks containing $8 \mathrm{~W}$ juveniles compared to those containing 2 or $4 W$ juveniles (Fig. 3a, Table 5). At a density of 8 juveniles tank ${ }^{-1}$, fewer $W$ juveniles died when $C$ juveniles were added to them $(2 W+6 C)$ compared to the proportion of $W$ that died when $W$ juveniles existed alone ( $2 W+6 W$; Fig. 3a). Survival of $W$ juveniles at a density of 4 juveniles tank ${ }^{-1}$ was similar when $C$ juveniles were added to $W$ juveniles $(2 W+2 C)$ and when $W$ juveniles existed alone $(2 W+$

Table 3. Penaeus plebejus. Asymmetrical analysis of variance used to determine how the proportional survival of wild $(W)$ juveniles is affected by competition for food between $W$ and captive-bred $(C)$ juveniles. The analysis examines the effect of increasing the density (ID) of juveniles and assesses the effect of adding $C$ to $W$ juveniles (CA). $p$ values in bold denote statistically significant effects at $\alpha=0.05$. For each treatment, $\mathrm{n}=3$ replicate tanks. Variances among treatments were homogeneous (Cochran's test: $C=0.25 ; \mathrm{p}=1$ )

\begin{tabular}{|lccrc|}
\hline Source of variation & df & MS & $F$ & $p$ \\
\hline Among all treatments & 4 & 0.24 & 3.71 & $\mathbf{0 . 0 4}$ \\
Control vs. Non-controls & 1 & 0.20 & 3.11 & 0.11 \\
Among Non-controls & 3 & 0.26 & 3.92 & $\mathbf{0 . 0 4}$ \\
ID & 1 & 0.75 & 11.42 & $\mathbf{0 . 0 1}$ \\
CA & 1 & 0.02 & 0.31 & 0.59 \\
ID $\times$ CA & 1 & 0.00 & 0.0 & 0.99 \\
Residual & 10 & 0.07 & - & - \\
Total & 14 & - & - & - \\
\hline
\end{tabular}




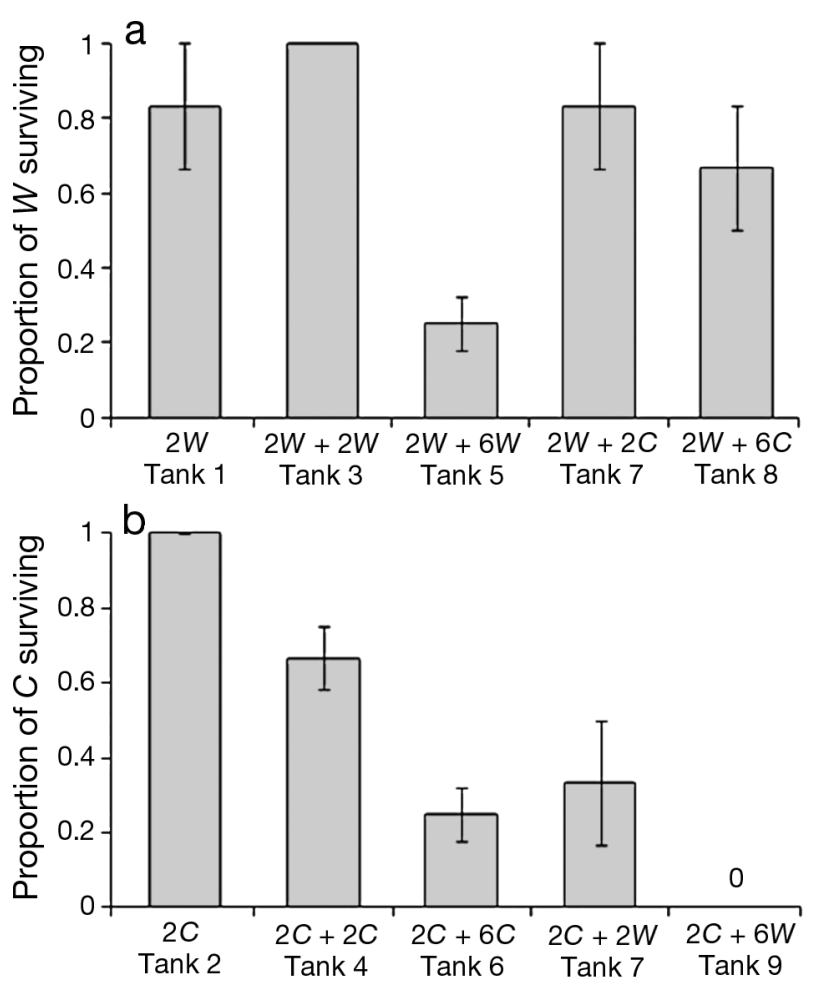

Fig. 3. Penaeus plebejus. Mean $( \pm \mathrm{SE})$ proportional survival of (a) wild $(W)$ and (b) captive-bred $(C)$ juveniles in an experiment examining competition for shelter within and between the 2 categories. Treatment tanks contained different combinations and densities of each category of juveniles (see Fig. 1)

$2 W_{i}$ Fig. 3a). The ANOVA found that CA did not have a significant effect on the survival of $W$ juveniles in the presence of a predator (Table 5).

When the density of $C$ individuals increased from 2 juveniles $\operatorname{tank}^{-1}$ to double this density and then 4

Table 4. Penaeus plebejus. Asymmetrical analysis of variance used to determine how the proportional survival of captive-bred $(C)$ juveniles is affected by competition for food between $C$ and wild $(W)$ juveniles. The analysis examines the effect of increasing the density (ID) of juveniles and assesses the effect of adding $W$ juveniles to $C$ juveniles (CA). $p$ values in bold denote statistically significant effects at $\alpha=0.05$. For each treatment, $\mathrm{n}=3$ replicate tanks. Variances among treatments were homogeneous (Cochran's test: $C=0.30 ; \mathrm{p}=1$ )

\begin{tabular}{|lrrrr|}
\hline Source of variation & df & MS & \multicolumn{1}{c|}{$F$} & $\mathrm{p}$ \\
\hline Among all treatments & 4 & 0.28 & 4.98 & $\mathbf{0 . 0 2}$ \\
Control vs. Non-controls & 1 & 0.15 & 2.71 & 0.13 \\
Among Non-controls & 3 & 0.32 & 5.79 & $\mathbf{0 . 0 2}$ \\
ID & 1 & 0.95 & 17.19 & $\mathbf{1 . 9 9} \times \mathbf{1 0}^{-3}$ \\
CA & 1 & 0.001 & 0.02 & 0.89 \\
ID $\times$ CA & 1 & 0.01 & 0.21 & 0.66 \\
Residual & 10 & 0.05 & - & - \\
Total & 14 & - & - & - \\
\hline
\end{tabular}

times this density in the presence of a predator, the survival of $C$ juveniles showed a significant continuous decline (Fig. 3b, Table 6). When $2 W$ juveniles were added to a control density of $2 C$ juveniles, the survival of $C$ juveniles (0.33) was nearly half of that observed when $2 C$ juveniles were added to a density of $2 C$ juveniles $(0.67$; Fig. $3 b)$. Similarly, when $6 C$ juveniles were added to $2 \mathrm{C}$ juveniles in the presence of a predator, survival was 0.25 but dropped to 0 when $6 \mathrm{~W}$ juveniles were added to $2 C$ juveniles (Fig. 3b). The effect of CA on the survival of $C$ juveniles was significant (Table 6), suggesting that survival of $C$ juveniles was affected as refuge in the presence of a predator became increasingly limited due to the addition of $W$ juveniles.

Table 5. Penaeus plebejus. Asymmetrical analysis of variance used to determine how the proportional survival of wild $(W)$ juveniles is affected by competition for shelter from predators between $W$ and captive-bred $(C)$ juveniles. The analysis examines the effect of increasing the density (ID) of juveniles and assesses the effect of adding $C$ juveniles to $W$ juveniles (CA). p values in bold denote statistically significant effects at $\alpha=0.05$. For each treatment, $\mathrm{n}=3$ replicate tanks. Variances among treatments were homogeneous (Cochran's test: $C=0.31 ; \mathrm{p}=1$ )

\begin{tabular}{|lrrrr|}
\hline Source of variation & df & MS & \multicolumn{1}{c|}{$F$} & $\mathrm{p}$ \\
\hline Among all treatments & 4 & 0.25 & 4.67 & $\mathbf{0 . 0 2}$ \\
Control vs. Non-controls & 1 & 0.31 & 5.76 & $\mathbf{0 . 0 4}$ \\
Among Non-controls & 3 & 0.23 & 4.25 & $\mathbf{0 . 0 4}$ \\
ID & 1 & 0.63 & 11.86 & $\mathbf{0 . 0 1}$ \\
CA & 1 & 0.05 & 0.88 & 0.37 \\
ID $\times$ CA & 1 & 0.26 & 4.80 & 0.05 \\
Residual & 10 & 0.05 & - & - \\
Total & 14 & - & - & - \\
\hline
\end{tabular}

Table 6. Penaeus plebejus. Asymmetrical analysis of variance used to determine how the proportional survival of captive-bred $(C)$ juveniles is affected by competition for shelter from predators between $C$ and wild $(W)$ juveniles. The analysis examines the effect of increasing the density (ID) of juveniles and assesses the effect of adding $W$ juveniles to $C$ juveniles (CA). p values in bold denote statistically significant effects at $\alpha=0.05$. For each treatment, $n=3$ replicate tanks. Variances among treatments were homogeneous (Cochran's test: $C=0.69 ; \mathrm{p}=0.28$ )

\begin{tabular}{|c|c|c|c|c|}
\hline Source of variation & $\mathrm{df}$ & MS & $F$ & $\mathrm{p}$ \\
\hline Among all treatments & 4 & 0.45 & 18.96 & $1.16 \times 10^{-4}$ \\
\hline Control vs. Non-controls & 1 & 1.14 & 47.56 & $4.21 \times 10^{-5}$ \\
\hline Among Non-controls & 3 & 0.23 & 9.42 & $2.92 \times 10^{-3}$ \\
\hline ID & 1 & 0.42 & 18.85 & $1.46 \times 10^{-3}$ \\
\hline CA & 1 & 0.26 & 10.65 & $8.52 \times 10^{-3}$ \\
\hline $\mathrm{ID} \times \mathrm{CA}$ & 1 & 0.01 & 0.22 & 0.65 \\
\hline Residual & 10 & 0.02 & - & - \\
\hline Total & 14 & - & - & - \\
\hline
\end{tabular}




\section{DISCUSSION}

The experimental design presented here may be used to predict the outcomes of competition between wild and captive-bred conspecifics following stock enhancement programmes. If the results reported here are shown to be consistent in larger experimental systems, at different times and in a range of natural conditions, competition for food and shelter induced simply by increasing population densities of Penaeus plebejus during stock enhancement could limit the survival of both wild and captive-bred $P$. plebejus. Between-category competition for refugia induced by adding captive-bred $P$. plebejus to wild conspecifics may also lead to the loss of captive-bred animals. In contrast, our results suggest that competition for food and shelter between these categories would not necessarily lead to the loss of wild individuals. For both wild and captive-bred P. plebejus, our first alternative hypothesis (i.e. mortality due to competition would increase as densities were increased) was supported by the laboratory experiments as both food and shelter became limited. However, the second alternative hypothesis (i.e. mortality due to competition between the 2 categories would be greater than mortality due to competition within wild $P$. plebejus, but lower than that within captive-bred P. plebejus) was not supported for either category as both food and shelter became limited.

As food and shelter from predators became limited at high densities of Penaeus plebejus, both wild and captive-bred juveniles exhibited significantly lower survivorship. This pattern is consistent with the theory of density dependence, which states that competition for essential resources can induce density-dependent mortality to lower a population's size (Keeley 2001). Although no previous studies have examined competition between wild and captive-bred penaeids, densitydependent survival in response to food limitation has been observed in $P$. esculentus and P. setiferus (Williams et al. 1996, Arnold et al. 2005). Since epiphytes contribute significantly to the juvenile penaeid diet (Kitting et al. 1984, Dall et al. 1990b, Loneragan et al. 1997), competition for the epiphytes present in our competition for food experiment may have led to higher mortality rates in both wild and captive-bred juveniles when densities were increased. The structural complexity of macrophytes can also limit predation mortality for penaeids by providing refuge or by reducing a predator's foraging efficiency (Primavera 1997, Ochwada et al. 2009). Competition for shelter may have, therefore, similarly increased at higher densities, leading to predation mortality for ineffective competitors.
The density-dependent effects of limitation of food and shelter were significant in the tanks containing 8 and 4 juveniles, respectively. These densities equate to $4 \times$ and $2 \times$ the maximum natural density observed in macrophytes for wild Penaeus plebejus (Young \& Carpenter 1977). For target release sites where availability of food is of greater concern than availability of shelter (i.e. systems with low predator densities), only releases of $P$. plebejus that result in total population densities $\geq 4 \times$ the natural density should lead to considerable mortality if the current laboratory findings can be extrapolated to the field. In release sites where predator densities are high relative to macrophytic cover, releasing P. plebejus to make up total densities of $\geq 2 \times$ the natural density is not recommended as it may result in significant mortality and limit the intended effects of stock enhancement. Once again, this recommendation would depend on the generality of our findings in wild conditions.

When food was limited, the effect of adding individuals from the alternative category on the survival of either wild or captive-bred juveniles did not differ significantly from the effect of adding individuals from their own category. Competition for food within each category of juveniles when present alone (i.e. intra-category competition) was therefore equivalent to competition between the 2 categories when in coexistence (i.e. inter-category competition). This implies that captive breeding does not hamper the developmental or genetic acquisition of the strategies used to find and exploit food in Penaeus plebejus. Although similar studies on competition have not been conducted on penaeid species, a small number of studies on non-penaeid species such as brown trout Salmo trutta have reported equivalent competitive abilities between wild and captive-bred individuals (e.g. Bohlin et al. 2002). The majority of research, however, points to a difference in the competitive abilities of wild and captive-bred conspecifics (Berejikian et al. 1997, Fleming et al. 1997, Berejikian et al. 2001). In terms of competition for food, Metcalfe et al. (2003) found that wild Atlantic salmon S. salar were competitively dominant over captive-reared conspecifics and attributed this to ineffective aggressive behaviours in captive-bred individuals, resulting in their failure to obtain feeding territories during direct contests with wild individuals. Berejikian \& Tezak (1999) observed a reversal in this pattern with captive-bred coho salmon Oncorhynchus kisutch outcompeting wild individuals and suggested that artificial rearing may have endowed captive-reared individuals with a phenotypic advantage in terms of their ability to acquire food. 
According to the Lotka-Volterra model of competition, the relative strength of competition between 2 categories of organisms versus the strength of competition within each category can determine whether the 2 categories will coexist through time (Begon et al. 1986). In general, coexistence can occur if intracategory competition is greater than inter-category competition (Chesson 2000, Hart \& Dustin 2009). If the effects of inter-category competition are stronger on a particular category than the effects of intracategory competition, then the weaker category is likely to be excluded (Boaventura et al. 2002). When the relative strengths of inter- and intra-category competition are equal, as shown here for wild and captive-bred Penaeus plebejus competing for food, coexistence is only possible if at least 1 of the categories exhibits over-compensatory density regulation (Chesson 2000, Münkemüller et al. 2009). Overcompensation occurs when individuals 'scramble' for a coveted resource to acquire as much of it as possible, leading to some organisms acquiring more than the minimum required and others acquiring insufficient amounts to sustain survival (de Jong 1976, Münkemüller \& Johst 2006, Münkemüller et al. 2009). Over-compensation therefore results in frequent peaks and crashes in at least 1 category's density (Münkemüller et al. 2009), providing a mechanism for intra-category competition to periodically exceed inter-category competition which in turn facilitates coexistence (Chesson 2000).

The feeding behaviour of juvenile Penaeus plebejus has not been studied directly, so it is difficult to determine whether over-compensation occurs in this species. There are, however, observations on related species which suggest a scramble feeding behaviour among penaeids. Juvenile P. semisulcatus and adult $P$. esculentus have been reported to feed throughout a $24 \mathrm{~h}$ cycle and digest as much food as possible shortly after consumption to support this continuous feeding mode (Hill \& Wassenberg 1987, Heales et al. 1996). Furthermore, the high rearing densities of the hatchery in the present study may have resulted in the development of scramble-for-food foraging behaviour among captive-bred P. plebejus juveniles or selected for individuals that possess this behaviour (Weber \& Fausch 2003). Thus, even if the results documented here were consistent in larger and more general experimental systems, scramble feeding behaviour in $P$. plebejus could potentially enable wild and captive-bred individuals to coexist via overcompensation when food is in short supply.

When refuge from predators was limited, the effect of competition between captive-bred and wild Penaeus plebejus on the survival of wild individuals was not significantly different from the effect of competition among wild individuals alone. In contrast, the survival of captive-bred individuals was significantly lower when wild individuals were added to them compared to when captive-bred individuals existed alone. These findings suggest that wild $P$. plebejus are better competitors for shelter than captive-bred individuals, possibly due to limited developmental acquisition of the cues used for predator detection and avoidance in captive-bred individuals as a result of being reared in an environment that is free of predatory stimuli (Einum \& Fleming 2001, OchwadaDoyle et al. 2010). Captive-bred blue crabs Callinectes sapidus and Salmo salar have been reported to be more susceptible to predation mortality than their wild conspecifics as a result of poor familiarity with natural predators and inexperience with the use of behavioural escape mechanisms (Einum \& Fleming 1997, Jonsson 1997, Davis et al. 2004, Houde et al. 2009). Therefore, similar behavioural deficits in captive-bred P. plebejus may have contributed to their higher mortality in the presence of predators. Such deficits may be mitigated through captive rearing in environments enriched with natural stimuli (e.g. predatory stimuli, simulated protective structures, natural prey) prior to stock enhancement. It should be noted, however, that the captive-bred individuals in this study may have been exposed to some form of predation whilst in the hatchery because cannibalism has been previously recorded among captivereared penaeids when held at high densities (Arnold et al. 2005).

According to the Lotka-Volterra model, the fact that the effect of inter-category competition for refuge on captive-bred Penaeus plebejus appeared to be stronger than the effect of intra-category competition suggests that exclusion of captive-bred individuals may eventually occur if our results apply to field conditions (Boaventura et al. 2002). In examining competitive interactions between the introduced signal crayfish Pacifastacus leniusculus and the indigenous Japanese crayfish Cambaroides japonicus, Usio et al. (2001) found that C. japonicus was the weaker competitor for shelter and that inter-specific competition was stronger than intraspecific competition among C. japonicus. They concluded that this explained the local extinction of $C$. japonicus and the rapid expansion of the range of $P$. leniusculus. Similar conclusions were reported for competing species of grass shrimp (Palaemonetes vulgaris versus Palaemon floridanus; Coen et al. 1981). 
If future research shows that our findings can be generalised across a range of scales, the exclusion of captive-bred Penaeus plebejus through competition for shelter may limit the long-term benefits of stock enhancement as a management tool aimed at supplementing depleted populations of this species in areas with limited macrophyte and high predator densities. This is an important finding in terms of assessing the feasibility of releasing penaeids in different systems, but is also interesting given that wild and captive-bred $P$. plebejus were previously shown to be equally capable of avoiding predation when present independently within an artificial macrophyte bed (Ochwada-Doyle et al. 2010). The difference between these 2 related studies suggests that once the 2 categories exist together, competition for shelter begins to play an important role. It also highlights the importance of examining competition for resources when captive-bred and wild conspecifics coexist before releases into the wild are conducted.

The findings described here were determined using experiments undertaken in controlled laboratory conditions. A number of natural factors that show greater variability in wild conditions could affect the way wild and captive-bred Penaeus plebejus respond to decreasing levels of food and shelter. In water temperatures that are higher than the temperatures recorded in the current study, for example, greater consumption rates due to higher metabolic requirements for juvenile P. plebejus (Haywood \& Staples 1993, Ochwada-Doyle et al. 2011) may increase competition for food between the 2 categories. Future experiments conducted at broader spatiotemporal scales and in a range of environmental conditions are needed to test the generality of the findings reported here and therefore assist in developing a more general model for intra-specific competition among $P$. plebejus in stocked systems. Future experiments should also use wild and captive-bred individuals sourced from multiple estuaries and multiple hatcheries, respectively, to enable broader conclusions to be drawn.

\section{CONCLUSION}

This research highlights the importance of investigating competition between wild and captive-bred animals prior to implementing stock enhancement programmes. It also demonstrates the importance of determining the carrying capacity of targeted release sites prior to stock enhancement in relation to the known requirements (e.g. diet and shelter) of a can- didate species and then releasing captive-bred individuals at densities that maintain a site's ability to support the projected total biomass (Munro \& Bell 1997, Loneragan et al. 2001, Taylor et al. 2005). If studies such as this can be replicated across several temporal and spatial scales for Penaeus plebejus and other candidates for stock enhancement, their findings may enable some of the predicted ecological consequences of stock enhancement to be compared with its intended benefits. This will assist in identifying situations in which stock enhancement may be an effective response to population loss.

Acknowledgements. This work was completed as part of a $\mathrm{PhD}$ candidature and supported in part by grants from the New South Wales Recreational Saltwater Fishing Trust (no. L30), the Australian Research Council (no. LP0775000) and the New South Wales Department of Primary Industries. The project was carried out with UNSW animal care and ethics approval (no. 06/88A). We thank A. Poore, D. Collins, UNSW staff and volunteers from the Merimbula Fishing Club for their assistance during the study. We also thank the 3 anonymous reviewers and 3 anonymous thesis examiners for their invaluable comments and suggestions on this work.

\section{LITERATURE CITED}

Agnalt AL, van der Meeren GI, Jorstad KE, Noess $\mathrm{H}$ and others (1999) Stock enhancement of European lobster (Homarus gammarus): a large-scale experiment off South-western Norway. In: Howell BR, Moksness E, Svasand T (eds) Stock enhancement and sea ranching. Fishing News Books, Oxford, p 401-419

Araki H, Cooper B, Blouin MS (2007) Genetic effects of captive breeding cause a rapid, cumulative fitness decline in the wild. Science 318:100-103

Arnold SJ, Sellars MJ, Crocos PJ, Coman GJ (2005) Response of juvenile brown tiger shrimp (Penaeus esculentus) to intensive culture conditions in a flow through tank system with three-dimensional artificial substrate. Aquaculture 246:231-238

Baldwin JD, Bass AL, Bowen BW, Clark WH (1998) Molecular phylogeny and biogeography of the marine shrimp Penaeus. Mol Phylogenet Evol 10:399-407

Begon M, Harper JL, Townsend CR (1986) Ecology. Individuals, populations and communities. Blackwell, Oxford

> Bell JD, Bartley DM, Lorenzen K, Loneragan NR (2006) Restocking and stock enhancement of coastal fisheries: potential, problems and progress. Fish Res 80:1-8

Bell JD, Leber KM, Blankenship HL, Loneragan NR, Masuda R (2008) A new era for restocking, stock enhancement and sea ranching of coastal fisheries resources. Rev Fish Sci 16:1-9

Berejikian BA, Tezak EP (1999) Competitive differences between newly emerged offspring of captive-reared and wild coho salmon. Trans Am Fish Soc 128:832-839

Berejikian BA, Tezak EP, Schroder SL, Knudsen CM, Hard JJ (1997) Reproductive behavioural interactions between wild and captively reared coho salmon (Oncorhynchus kisutch). J Mar Sci 54:1040-1050 
Berejikian BA, Tezak EP, LaHood SL, Beall E (2001) Male competition and breeding success in captively reared and wild coho salmon (Oncorhynchus kisutch). Can J Fish Aquat Sci 58:804-810

Blankenship HL, Leber KM (1995) A responsible approach to marine stock enhancement. Am Fish Soc Symp 15: 167-175

> Boaventura D, Cancela da Fonseca L, Hawkins SJ (2002) Analysis of competitive interactions between the limpets Patella depressa Pennant and Patella vulgata L. on the northern coast of Portugal. J Exp Mar Biol Ecol 271: 171-188

Bohlin TL, Sundstrom F, Johnsson JI, Hojesjo J, Pettersson J (2002) Density-dependent growth in brown trout: effects of introducing wild and hatchery fish. J Anim Ecol 71: 683-692

Bose M, Sarrazin F (2007) Competitive behaviour and feeding rate in a reintroduced population of griffon vultures Gyps fulvus. Ibis 149:490-501

Branch GM (1984) Competition between marine organisms: ecological and evolutionary implications. Oceanogr Mar Biol Annu Rev 22:458-627

> Chesson P (2000) Mechanisms of maintenance of species diversity. Annu Rev Ecol Syst 31:343-366

> Coen LD, Heck KL, Abele LG (1981) Experiments on competition and predation among shrimps of seagrass meadows. Ecology 62:1484-1493

Connell JH (1983) On the prevalence and relative importance of interspecific competition: evidence from field experiments. Am Nat 122:661-696

Cook P, Sweijd N (1999) The potential for abalone ranching and enhancement in South Africa. In: Howell BR, Moksness $E$, Svasand $T$ (eds) Stock enhancement and sea ranching. Fishing News Books, Oxford, p 453-467

Courtney AJ, Montgomery SS, Die DJ, Andrew NL, Cosgrove MG, Blount C (1995) Maturation in the female eastern king prawn Penaeus plebejus from coastal waters of eastern Australia, and considerations for quantifying egg production in penaeid prawns. Mar Biol 122: 547-556

Courtney AJ, Cosgrove M, Mayer D, Vance DJ (2002) Developing indicators of recruitment and effective spawner stock levels in eastern king prawns (Penaeus plebejus), Queensland Department of Primary Industries, Brisbane

Dall W, Hill B, Rothlisberg P, Sharples D (1990a) Reproduction. In: Blaxter JHS, Southward AJ (eds) The biology of the Penaeidae. Advances in marine biology, Vol 27. Academic Press, London, p 251-281

Dall W, Hill BJ, Rothlisberg PC, Staples DJ (1990b) Food and feeding. In: Blaxter JHS, Southward AJ (eds) The biology of the Penaeidae. Advances in marine biology, Vol 27. Academic Press, London, p 315-332

> Davis JLD, Young-Williams AC, Aguilar R, Carswell BL and others (2004) Differences between hatchery-raised and wild blue crabs: implications for stock enhancement potential. Trans Am Fish Soc 133:1-14

de Jong G (1976) A model for competition for food; frequency-dependent models. Am Nat 110:1013-1027

Einum S, Fleming I (1997) Genetic divergence and interactions in the wild among native, farmed and hybrid Atlantic salmon. J Fish Biol 50:634-651

Einum S, Fleming IA (2001) Implications of stocking: ecological interactions between wild and released salmonids. Nord J Freshw Res 75:56-70
Flegel TW (2007) The right to refuse revision in the genus Penaeus. Aquaculture 264:2-8

Flegel TW (2008) Confirmation of the right to refuse revision in the genus Penaeus. Aquaculture 280:1-4

- Fleming IA, Gross MR (1993) Breeding success of hatchery and wild coho salmon (Oncorhynchus kisutch) in competition. Ecol Appl 3:230-245

Fleming IA, Lamberg A, Jonsson B (1997) Effects of early experience on the reproductive performance of Atlantic salmon. Behav Ecol 8:470-480

Fox J (2008) Applied regression analysis and generalized linear models, 2nd edn. Sage, Los Angeles, CA

Hart SP, Dustin JM (2009) Spatial arrangement affects population dynamics and competition independent of community composition. Ecology 90:1485-1491

Haywood MDE, Staples DJ (1993) Field estimates of growth and mortality of juvenile banana prawns (Penaeus merguiensis). Mar Biol 116:407-416

Heales DS, Vance DJ, Loneragan NR (1996) Field observations of moult cycle, feeding behaviour, and diet of small juvenile tiger prawns Penaeus semisulcatus in the Embley River, Australia. Mar Ecol Prog Ser 145:43-51

$>$ Heck KL, Thoman TA (1984) The nursery role of seagrass meadows in the upper reaches of the Chesapeake Bay. Estuaries 7:70-92

Hill B, Wassenberg T (1987) Feeding behaviour of adult tiger prawns, Penaeus esculentus, under laboratory conditions. Mar Freshw Res 38:183-190

Hill BJ, Wassenberg TJ (1993) Why are some prawns found in seagrass? An experimental study of brown (Penaeus esculentus) and grooved ( $P$. semisulcatus) tiger prawns. Mar Freshw Res 44:221-227

> Hixon MA, Jones GP (2005) Competition, predation and density dependent mortality in demersal marine fishes. Ecology 86:2847-2859

Holbrook SJ, Schmitt RJ (2002) Competition for shelter space causes density-dependent predation mortality in damselfishes. Ecology 83:2855-2868

Houde ALS, Fraser DJ, Hutchings JA (2009) Fitness-related consequences of competitive interactions between farmed and wild Atlantic salmon at different proportional representations of wild-farmed hybrids. ICES J Mar Sci 67:657-667

Jonsson B (1997) A review of ecological and behavioural interactions between cultured and wild Atlantic salmon. ICES J Mar Sci 54:1031-1039

Keeley ER (2001) Demographic responses to food and space competition by juvenile steelhead trout. Ecology 82: 1247-1259

> Kenyon RA, Loneragan NR, Hughes JM (1995) Habitat type and light affect sheltering behavior of juvenile tiger prawns (Penaeus esculentus Haswell) and success rates of their fish predators. J Exp Mar Biol Ecol 192:87-105

Kirkman H, Reid DD (1979) A study of the role of the seagrass Posidonia australis in the carbon budget of an estuary. Aquat Bot 7:173-183

Kitting CL, Fry B, Morgan MD (1984) Detection of inconspicuous epiphytic algae supporting food webs in seagrass meadows. Oecologia 62:145-149

> Kleiman DG (1989) Reintroduction of captive mammals for conservation. Bioscience 39:152-161

- Lachance S, Magnan P (1990) Performance of domestic, hybrid and wild strains of brook trout, Salvelinus fontinalis, after stocking: the impact of intra- and interspecific competition. Can J Fish Aquat Sci 47:2278-2284 
Lavery S, Chan TY, Tam YK, Chu KH (2004) Phylogenetic relationships and evolutionary history of the shrimp genus Penaeus s.l. derived from mitochondrial DNA. Mol Phylogenet Evol 31:39-49

Leber KM (1999) Rationale for an experimental approach to stock enhancement. In: Howell BR, Moksness E, Svåsand $\mathrm{T}$ (eds) Stock enhancement and sea ranching. Fishing News Books, Oxford, p 63-75

Lenanton RC, Ayvazian SG, Dibden C, Jenkins G, Sarre G (1999) The use of stock enhancement to improve the catch rates of black bream, Acanthopagus butcheri (Munro) for Western Australian recreational fishers. In: Howell BR, Moksness E, Svasand T (eds) Stock enhancement and sea ranching. Fishing News Books, Oxford, p 219-230

Liu H, Loneragan NR (1997) Size and time of day affect the response of postlarvae and early juvenile grooved tiger prawns Penaeus semisulcatus De Haan (Decapoda: Penaeidae) to natural and artificial seagrass in the laboratory. J Exp Mar Biol Ecol 211:263-277

> Loneragan NR, Bunn SE, Kellaway DM (1997) Are mangroves and seagrasses sources of organic carbon for penaeid prawns in a tropical Australian estuary? A multiple stable-isotope study. Mar Biol 130:289-300

Loneragan NR, Haywood MDE, Heales DS, Kenyon RA, Pendrey RP, Vance DJ (2001) Estimating the influence of prawn stocking density and seagrass type on the growth of juvenile tiger prawns (Penaeus semisulcatus): results from field experiments in small enclosures. Mar Biol 2001:343-354

Mason JC, Chapman DW (1965) Significance of early emergence, environmental rearing capacity, and behavioral ecology of juvenile coho salmon in stream channels. J Fish Res Board Can 22:173-190

> McLaughlin PA, Lemaitre R, Felder D (2008) A reply to T.W. Flegel. Aquaculture 275:370-373

> Metcalfe NB, Valdimarsson SK, Morgan IJ (2003) The relative roles of domestication, rearing environment, prior residence and body size in deciding territorial contests between hatchery and wild juvenile salmon. J Appl Ecol 40:535-544

Minello TJ, Zimmerman RJ (1985) Differential selection for vegetative structure between juvenile brown shrimp (Penaeus aztecus) and white shrimp (P. setiferus), and implications in predator-prey relationships. Estuar Coast Shelf Sci 20:707-716

Molony B, Lenanton RCJ, Jackson G, Norriss J (2003) Stock enhancement as a fisheries management tool. Rev Fish Biol Fish 13:409-432

Montgomery SS (1990) Movements of juvenile eastern king prawns, Penaeus plebejus, and identification of stock along the east coast of Australia. Fish Res 9:189-208

> Montgomery SS, Courtney AJ, Blount C, Stewart J, Die DJ, Cosgrove M, O'Neill MF (2007) Patterns in the distribution and abundance of female eastern king prawns, Melicertus plebejus (Hess, 1865), capable of spawning and reproductive potential in waters off eastern Australia. Fish Res 88:80-87

Münkemüller T, Johst K (2006) Compensatory versus overcompensatory regulation: implications for metapopulation persistence in dynamic landscapes. Ecol Model 197: 171-178

Münkemüller T, Bugmann H, Johst K (2009) Hutchinson revisited: patterns of density regulation and the coexistence of strong competitors. J Theor Biol 259:109-117
Munro JL, Bell JD (1997) Enhancement of marine fisheries resources. Rev Fish Sci 5:185-222

> Ochwada F, Loneragan NR, Gray CA, Suthers IM, Taylor MD (2009) Complexity affects habitat preference and predation mortality in postlarval Penaeus plebejus: implications for stock enhancement. Mar Ecol Prog Ser 380:161-171

Ochwada-Doyle FA, Gray CA, Loneragan NR, Taylor MD (2010) Using experimental ecology to understand stock enhancement: comparisons of habitat related predation on wild and hatchery reared Penaeus plebejus Hess. J Exp Mar Biol Ecol 390:65-71

> Ochwada-Doyle FA, Gray CA, Loneragan NR, Taylor MD, Suthers IM (2011) Spatial and temporal variability in the condition of postlarval and juvenile Penaeus plebejus sampled from a population subjected to pilot releases. Aquacult Environ Interact 2:15-25

> Olabarria C, Underwood AJ, Chapman MG (2002) Appropriate experimental design to evaluate preferences for microhabitat: an example of preferences by species of microgastropods. Oecologia 132:159-166

Pérez Farfante I, Kensley B (1997) Penaeoid and sergestoid shrimps and prawns of the world: keys and diagnoses for the families and genera. Museum National d'Histoire Naturelle, Paris

Pile AJ, Lipcius RN, van Montfrans J, Orth RJ (1996) Density-dependent settler-recruit-juvenile relationships in blue crabs. Ecol Monogr 66:277-300

Primavera JH (1997) Fish predation on mangrove-associated penaeids: the role of structures and substrate. J Exp Mar Biol Ecol 215:205-216

Racek AA (1959) Prawn investigations in eastern Australia. Res Bull State Fish NSW 6:1-57

Reid DD, Montgomery SS (2005) Creel survey based estimation of recreational harvest of penaeid prawns in four southeastern Australian estuaries and comparison with commercial catches. Fish Res 74:169-185

Rockwood L (2006) Population regulation. In: Rockwood L (ed) Introduction to population ecology. Wiley-Blackwell, Oxford, p 66-76

- Rothlisberg PC, Church JA, Fandry CB (1995) A mechanism for near-shore concentration and estuarine recruitment of postlarval Penaeus plebejus Hess (Decapoda, Penaeidae). Estuar Coast Shelf Sci 40:115-138

Ruello NV (1975) Geographical distribution, growth and breeding migration of eastern Australian king prawn $P e-$ naeus plebejus Hess. Aust J Mar Freshw Res 26:343-354

> Ryer C (2004) Comparison of genetically based antipredator behaviour in hatchery and wild coho fry from a coastal Oregon river: interpreting a negative result. J Fish Biol 64:1413-1418

Sarrazin F, Barbault R (1996) Reintroduction: challenges and lessons for basic ecology. Trends Ecol Evol 11:474-478

Schoener TW (1983) Field experiments on interspecific competition. Am Nat 122:240-285

Skilleter GA, Olds A, Loneragan NR, Zharikov Y (2005) The value of patches of intertidal seagrass to prawns depends on their proximity to mangroves. Mar Biol 147:353-365

Solomon ME (1949) The natural control of animal populations. J Anim Ecol 18:1-35

> Støttrup JG, Sparrevohn CR (2007) Can stock enhancement enhance stocks? J Sea Res 57:104-113

Taylor MD (2010) Marine stocking in Victoria; a preliminary assessment of the potential suitability of Victorian waters selected for fish releases. UNSW Global, Sydney 
Taylor MD, Palmer PJ, Fielder DS, Suthers IM (2005) Responsible estuarine finfish stock enhancement: an Australian perspective. J Fish Biol 67:299-331

Tilman D (1987) The importance of the mechanisms of interspecific competition. Am Nat 129:769-774

Underwood AJ (1997) Experiments in ecology. Cambridge University Press, Cambridge

Usio N, Konishi M, Nakano S (2001) Species displacement between an introduced and a 'vulnerable' crayfish: the role of aggressive interactions and shelter competition. Biol Invasions 3:179-185

> Walls SC (1998) Density dependence in a larval salamander: the effects of interference and food limitation. Copeia 1998:926-935

> Weber ED, Fausch KD (2003) Interactions between hatchery and wild salmonids in streams: differences in biology and evidence for competition. Can J Fish Aquat Sci 60: 1018-1036

Webster MS (2004) Density dependence via intercohort competition in a coral-reef fish. Ecology 85:986-994

Webster PJ, Rowden AA, Attrill MJ (1998) Effect of shoot density on the infaunal macro-invertebrate community

Editorial responsibility: Lisandro Benedetti-Cecchi, Pisa, Italy within a Zostera marina seagrass bed. Estuar Coast Shelf Sci 47:351-357

Wickström H, Westin L, Clevestam P (1996) The biological and economic yield from a long-term eel-stocking experiment. Ecol Freshw Fish 5:140-147

Williams AS, Davis DA, Arnold CR (1996) Density-dependent growth and survival of Penaeus setiferus and Penaeus vannamei in a semi-closed recirculating system. J World Aquacult Soc 27:107-112

> Woodworth LM, Montgomery ME, Briscoe DA, Frankham R (2002) Rapid genetic deterioration in captive populations: causes and conservation implications. Conserv Genet 3:277-288

Young PC (1975) Preliminary observations on the environment and biology of the juvenile king prawn (Penaeus plebejus) in Moreton Bay. Australian Government Public Service, Canberra

Young PC (1978) Moreton Bay, Queensland - nursery area for juvenile penaeid prawns. Aust J Mar Freshw Res 29:55-75

> Young PC, Carpenter SM (1977) Recruitment of post-larval penaeid prawns to nursery areas in Moreton Bay, Queensland. Aust J Mar Freshw Res 28:745-773

Submitted: June 7, 2011; Accepted: January 13, 2012 Proofs received from author(s): March 20, 2012 